\title{
No evidence for an ethnic influence on basal metabolism: an examination of data from India and Australia
}

\author{
Mario J. Soares ${ }^{1,2 *}$ Leonard S. Piers ${ }^{2}$, Kerin $O^{\prime} \mathrm{Dea}^{2}$ and Prakash S. Shetty ${ }^{3}$ \\ ${ }^{1}$ School of Nutrition and Public Health and ${ }^{2}$ Deakin Institute of Human Nutrition, Deakin University, 336 Glenferrie Road, \\ Malvern 3144, Victoria, Australia \\ ${ }^{3}$ London School of Hygiene and Tropical Medicine, Human Nutrition Unit, 2 Taviton Street, London WClH OBT, UK
}

(Received 11 March 1997 - Revised 4 September 1997 - Accepted 14 October 1997)

\begin{abstract}
A lower BMR of Indians, when compared with Westerners matched for age, sex, and either surface area or body weight, has often been reported in the literature and has been interpreted to reflect an ethnic influence on BMR. To determine the contribution of body composition to these observed differences in BMR, we analysed the data on ninety-six Indians and eighty-one Caucasian Australians of both sexes, aged 18-30 years, studied in Bangalore, India and Melbourne, Australia. Absolute BMR and BMR adjusted for body weight were significantly lower in Indians when compared with Australians of the corresponding sex. However, BMR adjusted for fat-free mass (FFM) in men, and BMR adjusted for FFM and fat mass (FM) in women, were not significantly different between the two groups. Stepwise regression of FFM, FM, sex $(0=$ women; $1=$ men) and ethnicity $(0=$ Indian; $1=$ Australian) on BMR, resulted in the following relationship for the combined data on all subjects: $B M R=88.7 \times$ FFM $(\mathrm{kg})+1713\left(n-177 ; r 0.92 ; r^{2} 0.85\right.$; SEE $\left.425 \mathrm{~kJ}\right)$. The Indian equations of Hayter \& Henry (1994), based on body weight, resulted in a significant bias (measured - predicted BMR) of 318 $(\mathrm{SE} 54) \mathrm{kJ} / \mathrm{d}$ in Indian men and $-409(\mathrm{SE} 70) \mathrm{kJ} / \mathrm{d}$ in Indian women. The equation of Cunningham (1991), based on FFM, accurately predicted the BMR of Indian men, Indian women and Australian men. The small but significant bias of 185 (SE 61) kJ/d in Australian women, may be explained by the significant contribution of FM to BMR in this group. The present study does not provide any evidence for an ethnic influence on basal metabolism. The results strongly support the use of FFM, rather than body weight, for the prediction of BMR in population groups of varying body size and composition. This would allow an accurate estimation of BMR and hence energy requirements in population groups worldwide.
\end{abstract}

Basal metabolic rate: Ethnic origin: Body composition

A significant development over the last decade that has influenced our understanding of the energy requirements of human subjects has been the publication of the Food and Agriculture Organization/World Health Organization/United Nations University (FAO/WHO/UNU) (1985) report Energy and Protein Requirements. The report establishes two principles: (a) that all estimates of energy requirements should be based on measures of energy expenditure, and (b) that the BMR should form the basis of the factorial approach to estimate total energy expenditure of individuals, communities and population groups. In situations where actual measures are not feasible, BMR can be predicted from recommended equations. These equations are based on body weight and are age- and sex- specific (FAO/WHO/UNU, 1985; Schofield et al. 1985). The adoption of the FAO/WHO/UNU (1985) report for purposes of estimating energy requirements has hence brought into focus the accuracy of BMR measurement, its physiological variability and the validity of its prediction in population groups worldwide.

As part of their analysis of the Food and Agriculture Organization's database on BMR, Schofield et al. (1985) made the observation that measured BMR of Indians were significantly lower for the same body weight than those predicted from European and/or American data. Previous Indian studies had consistently shown that the measured BMR of Indians, expressed per unit body surface area, were $5-18 \%$ lower than the American standards then in vogue

\footnotetext{
Abbreviations: ANCOVA, analysis of covariance; CED, chronically energy-deficient; FAO/WHO/UNU, Food and Agriculture Organization/World Health Organization/United Nations University; FFM, fat-free mass; FM, fat mass; OM, organ mass; SMM, skeletal muscle mass.

*Corresponding author: Dr Mario Soares, fax +61 39244 5338, email mjsoares@deakin.edu.au
} 
(Mason \& Benedict, 1931; Mukherjee \& Gupta, 1931; Krishnan \& Vareed, 1932; Rahman, 1936; Rajagopal, 1938; Niyogi et al. 1939; Khanna \& Manchanda, 1946; Shiv Kumar \& Sachar, 1961; Banerjee, 1962; Mason et al. 1963). More recent studies demonstrated that the measured BMR of Indians was significantly lower than predicted from body weight, using equations developed on Europeans and Americans (Soares \& Shetty, 1984, 1988; McNeill et al. 1987; Shetty et al. 1988; Piers \& Shetty, 1993). These differences in BMR were often accepted as evidence for an ethnic influence on basal metabolism, although the methodology of measurement, climate and habitual protein intake were likely to influence the BMR of Indians (Wilson 1945; Soares \& Shetty, 1988). However, the reiteration of an old observation served to rekindle an interest in this area. In subsequent analyses of BMR, Henry \& Rees (1988, 1991) extended the work of Quenouille et al. (1951) and Schofield et al. (1985). They concluded that, compared with Europeans, a lower predicted BMR for the same body weight was evident for most Asian groups living in the tropics, and was not a phenomenon unique to Indians.

Over the years most studies that demonstrated a lower BMR of Indians, did so when values were compared with Western standards. There is evidence to suggest that the standards of Harris \& Benedict (1919) have a precision of $14 \%$ (Roza \& Shizgal, 1984). These equations overestimate the BMR of modern-day Europeans and Americans by $10-15 \%$ (Solomon et al. 1982; Stoner, 1982; Daly et al. 1985; Owen et al. 1986, 1987; Mifflin et al. 1990; Clark \& Hoffer, 1991). It is now also clear that the Schofield et al. (1985) equations (developed from the $\mathrm{FAO} / \mathrm{WHO} / \mathrm{UNU}$ database) overestimate the BMR of Europeans and those of European descent (de Boer et al. 1988; Hayter \& Henry, 1994; Klausen et al. 1997; Piers et al. 1997). Much of the error with the Schofield et al. (1985) equations was due to Italian data that were not representative of the general Italian population (Hayter \& Henry, 1994; Shetty et al. 1996). However, even with the exclusion of the Italian data, there still were differences in the BMR of Indians and Chinese as compared with North Europeans and Americans. Newer equations were then derived for temperate (North Europeans and Americans), and tropical (Indians and Chinese) populations (Hayter \& Henry, 1994). While we have validated the North European and American equations for Australians of European descent (Piers et al. 1997), the validity of the Indian or Chinese equations for their respective populations have yet to be determined.

It is generally accepted that there is a decline in BMR on moving from a temperate to a tropical environment, such that the BMR expressed per $\mathrm{kg}$ body weight is similar in Europeans resident in the tropics, to that of Indians (Munro, 1950). In a recent longitudinal study with a review on the subject, Hayter \& Henry (1993) demonstrated that when individuals from the tropics migrated to a temperate environment, their BMR expressed per $\mathrm{kg}$ body weight was comparable to that of their temperate counterparts. It was not possible to estimate the magnitude of the climatic effect on BMR, since this study had no measurements of BMR before migration. However, the conclusion supported earlier findings that showed no differences in BMR of Asians living in Britain when compared with Europeans
(Mahadeva, 1954; Henry et al. 1987; Ulijaszek \& Strickland, 1991). Hence it is plausible to ascribe some of the variance in BMR to climatic effects, though the magnitude of the effect is debatable and would depend on the experimental design, subject selection and duration of migration (Hayter \& Henry, 1993).

Some studies have measured BMR and body composition as part of 'between-country' comparisons. While absolute BMR has been lower, BMR expressed per $\mathrm{kg}$ fatfree mass (FFM) has been shown to be 'higher' in Thai and Gambian women compared with their Scottish counterparts (Lawrence et al. 1988). Also, Asian and African men had 'higher' BMR per kg FFM than their European counterparts (de Boer et al. 1988). The manner of normalization of data for inter-group comparisons is important. The general practice of correcting for differences in body size by dividing BMR by FFM, is mathematically biased and will lead to the erroneous conclusion that the BMR is higher in those individuals with a smaller FFM (Ravussin \& Bogardus, 1989). These artifacts are eliminated by using an analysis of covariance (ANCOVA) (Ravussin \& Bogardus, 1989).

A 'higher' BMR per kg FFM could, however, reflect an alteration in the composition of FFM per se. FFM is a composite of tissues with differing metabolic rates. It may be viewed as consisting of organ mass (OM) which is metabolically more active, and skeletal muscle mass (SSM), which has a relatively lower metabolic rate in the resting state. Over a range of FFM the relative amounts of OM and SSM will vary. So a 'higher' BMR per kg FFM may be the consequence of a greater proportion of $\mathrm{OM}$ within FFM. Such results have been documented in chronically energy-deficient (CED) individuals in whom SMM was significantly reduced (Soares \& Shetty, 1991; Shetty, 1993; Soares et al. 1994). The body composition data of Garby \& Lammert (1992) and the analyses of Weinsier et al. (1992) collectively indicate that this notion is true for normally-nourished men and women as well.

Thus, it was clear that before one ascribed population differences in BMR to 'ethnic' influences on BMR, it was necessary to establish: (1) that none of the subjects were CED (any grade), (2) that the standard or reference BMR used for comparison was applicable, (3) that inter-group comparisons were made using the best determinant of BMR, (4) that appropriate statistical procedures were employed, and (5) that differences in BMR were not explained by differences in body composition. In an attempt to resolve these issues we have examined the BMR and body composition of a number of young individuals on ad libitum food intakes, belonging to two distinct ethnic groups (Indians and Australians of European ancestry) and living under different climatic conditions in Bangalore, India and Melbourne, Australia. We analysed our data to answer the following related questions: (1) were there differences in the BMR of Indians and Australians when matched for age, sex and body weight? (2) if so, could these differences be explained by differences in body composition? (3) how accurate were the new prediction equations of Hayter \& Henry (1994) for Indians? (4) could a simple relationship between $\mathrm{BMR}$ and body composition 
be used to predict the BMR of different ethnic groups, living in different climatic locations?

\section{Subjects and methods}

\section{Subjects}

Subjects were healthy men and women aged between 18 and 30 years, on ad libitum energy intakes over a wide range of BMI (from 17 to $32.6 \mathrm{~kg} / \mathrm{m}^{2}$ ). Indian subjects with BMI between 17 and 18.5 but from high socio-economic background were included in the analyses since we had earlier demonstrated that they had BMR similar to those of individuals with $\mathrm{BMI} \geq 18.5 \mathrm{~kg} / \mathrm{m}^{2}$ (Soares \& Shetty, 1991; Piers \& Shetty, 1993). All subjects were selected after a medical history and clinical examination revealed no systemic disease or signs and symptoms of vitamin deficiencies. None of the subjects was on chronic medication and the women did not use oral contraceptive agents. The database of 177 subjects consisted of forty-six Indian men and fifty Indian women, thirty-nine Australian men and forty-two Australian women. All Australians were of European ancestry as judged from their family history.

\section{BMR}

The Indian data were collected at the Nutrition Research Centre, Department of Physiology, St John's National Academy of Health Sciences, Bangalore, India. Measurements of $\mathrm{O}_{2}$ consumption and $\mathrm{CO}_{2}$ production were made on a Hartmann \& Braun Metabolator (Hartmann \& Braun $A G$, Frankfurt, Germany) that operated on the principle of indirect open-circuit calorimetry and necessitated the use of a noseclip and mouthpiece. Measurements were made in duplicate for $10 \mathrm{~min}$ each, with a $10 \mathrm{~min}$ interval between measures. Details of the system and calibration procedures have been published elsewhere (Soares et al. 1989). The Australian data were collected at the Deakin Institute of Human Nutrition, Deakin University, Melbourne, Australia using standardized methodology (Piers et al. 1997). In brief, BMR was measured for $30 \mathrm{~min}$ using a Deltatrac II (Datex, Finland), which also operated on the principle of indirect open-circuit calorimetry but instead used a ventilated hood or canopy. The Deltatrac was calibrated on the morning of each measurement day against a gas mixture of known concentrations. Alcohol burns yielded a mean $\mathrm{CO}_{2}$ production: $\mathrm{O}_{2}$ consumption value of 0.67 (SD 0.02). The Hartmann \& Braun Metabolator had been validated against other indirect open-circuit calorimetry systems. In a crossover design, BMR measured on the Hartmann \& Braun (1460 (SE 65) kJ/d) and ventilated hood (1515 (SE 93) kJ/d) were not significantly different on the basis of a paired $t$ test (Soares et al. 1989). In another protocol, when the two instruments were connected in series arrangement (expired air from the metabolator was conducted along a tube fed into the ventilated hood), the measurement of BMR was also not different between the Hartmann \& Braun (1413 (SE 60) kJ/d) and the ventilated hood system (1410 (SE 74) kJ/d) (Soares et al. 1989).

\section{Body composition}

All anthropometric variables and the sum of four skinfolds (biceps, triceps, subscapular and supra-iliac) were measured by two experienced investigators (MJS, LSP) using standard methodology (Harrison et al. 1988). The equations of Durnin \& Womersley (1974) were used to estimate a two-compartment model of body composition, i.e. fat mass (FM) and FFM, for both ethnic groups studied. Repeated measurements were made in five subjects by the two observers. The inter-observer correlation coefficient was 0.95 for the sum of four skinfolds, with no significant differences between observers (paired $t$ test; $t-0.3$; $P=0.77$ ). A two-way ANOVA with replicates established the precision for the measurement of body fat to have a CV of $1.6 \%$ (SD of FM $0.29 \mathrm{~kg}$ ), while that for FFM was $0.6 \%$ (SD of FFM $0.30 \mathrm{~kg}$ ).

In separate studies of body composition in each country the skinfold method, using Durnin \& Womersley's (1974) equations, had been validated against estimates obtained from hydrodensitometry and total body water determinations using deuterium dilution. Mean values for bias in FFM between skinfolds and hydrodensitometry, were nonsignificant at 0.16 (SE 1.09) kg in Indian men and 0.67 (SE 0.90 ) $\mathrm{kg}$ in women (R. Kuriyan and A.V. Kurpad, personal communication). Mean bias in FFM between skinfolds and total body water was not significant at 0.73 (SE 0.70$) \mathrm{kg}$ in Australian men and not significant at 0.56 (SE 0.51 ) kg in Australian women (L. S. Piers, M. J. Soares and K. O'Dea, unpublished results).

BMR values $(\mathrm{kJ} / \mathrm{d})$ were predicted from the following equations:

Hayter \& Henry (1994) equation for North Europeans and Americans

$$
\begin{aligned}
\text { males: } & \mathrm{BMR}=51 \times \text { weight }(\mathrm{kg})+3500, \\
\text { females: } & \mathrm{BMR}=47 \times \text { weight }(\mathrm{kg})+2880 .
\end{aligned}
$$

Hayter \& Henry (1994) equation for Indians

$$
\begin{aligned}
\text { males: } & \mathrm{BMR}=39 \times \text { weight }(\mathrm{kg})+3533, \\
\text { females: } & \mathrm{BMR}=26 \times \text { weight }(\mathrm{kg})+3851 .
\end{aligned}
$$

Cunningham's (1991) equation (for either sex) based on FFM

$$
\mathrm{BMR}=90.4 \times \mathrm{FFM}(\mathrm{kg})+1548 .
$$

\section{Statistics}

All data are presented as means and standard deviations, unless otherwise stated. Bias is the difference between measured and predicted BMR and was analysed as suggested by Bland \& Altman (1986). Data were analysed by paired $t$ tests, and independent $t$ tests as appropriate. ANCOVA with body weight, FFM and FM as covariates was used to adjust for differences in BMR, after testing for parallelism (Kleinbaum et al, 1988). Stepwise, leastsquares linear regression analysis was used to relate BMR to significant predictor variables. The development of all equations in this study followed standard procedures. As a 
first step, $50 \%$ of the study population was randomly chosen and used to derive a preliminary equation. This equation was then tested on the population not used to derive the equation by examining the bias between measured and predicted BMR (Draper \& Smith, 1981; Kleinbaum et al. 1988). In addition, bias was correlated to predicted BMR. Lack of significant differences and lack of a significant correlation justified pooling of the data to derive the final equation. Statistical significance was accepted at the $5 \%$ level.

\section{Ethical approval}

Informed, written consent was obtained from each participant. The data on Indians were compiled as part of studies that had received prior approval by the Ethics Committee of St John's Medical College, Bangalore, India. The Australian component of the study was approved by Deakin University Ethics Committee, Deakin University, Melbourne, Australia.

\section{Results}

The results of anthropometric and body composition measurements are summarized in Table 1 . The Indian database included subjects with low BMI but of high socio- economic background and ad libitum food intake. To rule out the inclusion of subjects who may be classified as CED, we compared the BMR of individuals above and below the suggested BMI cut-off of $18.5 \mathrm{~kg} / \mathrm{m}^{2}$ (James et al. 1988). Measured BMR, adjusted for FFM, was not different in men with $\mathrm{BMI}<18.5 \mathrm{~kg} / \mathrm{m}^{2}$ when compared with those with $\mathrm{BMI} \geq 18.5 \mathrm{~kg} / \mathrm{m}^{2}$ (df 1,$43 ; F$ ratio $0 ; P=0.99$ ). Similarly, measured BMR adjusted for FFM was not different in women with $\mathrm{BMI}<18.5 \mathrm{~kg} / \mathrm{m}^{2}$ as compared with those with $\mathrm{BMI} \geq 18.5 \mathrm{~kg} / \mathrm{m}^{2}$ (df 1,$47 ; F$ ratio 0.35 ; $P=0 \cdot 56$ ). The subsequent analysis involving Indian men and women therefore included all subjects across the BMI range.

A two-way ANOVA with FFM as covariate was used to examine differences between sex and ethnic groups. There was no sex $x$ ethnic group interaction (df 1,$172 ; F$ ratio $1.17 ; P=0.28$ ) and no differences between ethnic groups (df 1,$172 ; F$ ratio $2.94 ; P=0.09$ ). However, sex differences approached statistical significance (df 1,$172 ; F$ ratio 3.75 ; $P=0.054$ ). Within each sex group, absolute BMR of Indians were significantly lower than those of Australians. BMR expressed per $\mathrm{kg}$ FFM was significantly higher in Indian men compared with Australian men (Table 2). When examined as a group, women (133 (SE 1.3) kJ/kg per d; $n$ 92) had higher BMR per kg FFM compared with men (120 (SE 1.0$) \mathrm{kJ} / \mathrm{kg}$ per d; $n 85$ ). Adjusted for body weight, BMR of Indian men (df 1,$82 ; F$ ratio $6.79 ; P=0.01$ ) and women

Table 1. Anthropometric and body composition data of Indian and Australian subjects

(Mean values and standard deviations)

\begin{tabular}{|c|c|c|c|c|c|c|c|c|}
\hline \multirow[b]{3}{*}{ Variables } & \multicolumn{4}{|c|}{ Men } & \multicolumn{4}{|c|}{ Women } \\
\hline & \multicolumn{2}{|c|}{ Indian ( $n$ 46) } & \multicolumn{2}{|c|}{ Australian ( $n$ 39) } & \multicolumn{2}{|c|}{ Indian ( $n 50)$} & \multicolumn{2}{|c|}{ Australian ( $n$ 42) } \\
\hline & Mean & SD & Mean & SD & Mean & SD & Mean & SD \\
\hline Age (years) & 20.2 & 2 & $25^{\star *}$ & 4 & 21 & 3 & $23^{* *}$ & 2 \\
\hline Body weight $(\mathrm{kg})$ & 59.9 & 6.7 & $76 \cdot 5^{\star \star}$ & $11 \cdot 7$ & 49.5 & $5 \cdot 5$ & $61 \cdot 0^{\star *}$ & 7.4 \\
\hline Height $(\mathrm{m})$ & 1.74 & 0.06 & $1.78^{\star \star}$ & 0.07 & 1.59 & 0.05 & $1.65^{\star \star}$ & 0.08 \\
\hline $\mathrm{BMI}\left(\mathrm{kg} / \mathrm{m}^{2}\right)$ & $19 \cdot 8$ & 2.2 & $24 \cdot 1^{\star \star}$ & $3 \cdot 1$ & 19.5 & 1.8 & $22 \cdot 4^{* *}$ & $2 \cdot 2$ \\
\hline Fat mass $(\mathrm{kg})$ & 9.6 & 3.5 & $13.5^{\star \star}$ & 5.9 & 14.4 & $3 \cdot 3$ & $18 \cdot 0^{\star *}$ & 4.0 \\
\hline Fat-free mass $(\mathrm{kg})$ & $50 \cdot 3$ & $4 \cdot 8$ & $63 \cdot 0^{* \star}$ & 7.7 & $35 \cdot 1$ & 3.2 & $43 \cdot 0^{\star \star}$ & 4.5 \\
\hline
\end{tabular}

Mean values were significantly different from those for Indians of the corresponding sex, ${ }^{* *} P<0.005$ (independent $t$ test).

Table 2. Absolute and adjusted BMR of Indian and Australian subjects (Mean values and standard deviations)

\begin{tabular}{|c|c|c|c|c|c|c|c|c|}
\hline & \multicolumn{4}{|c|}{ Men } & \multicolumn{4}{|c|}{ Women } \\
\hline & \multicolumn{2}{|c|}{ Indian ( $(46)$} & \multicolumn{2}{|c|}{ Australian ( $n$ 39) } & \multicolumn{2}{|c|}{ Indian $(n 50)$} & \multicolumn{2}{|c|}{ Australian ( $n$ 42) } \\
\hline & Mean & SD & Mean & SD & Mean & so & Mean & SD \\
\hline $\operatorname{BMR}(k J / d)$ & 6186 & 452 & $7312^{\star \star}$ & 774 & 4728 & 555 & $5617^{\star \star}$ & 528 \\
\hline $\begin{array}{l}\text { BMR per } \mathrm{kg} F F M(\mathrm{~kJ} / \mathrm{kg} \text { per d) } \\
\text { BMR }(\mathrm{kJ} / \mathrm{d}) \text { adiusted by ANCOVA for: }\end{array}$ & 124 & $9 \cdot 3$ & $117^{\star *}$ & 8.4 & 135 & $12 \cdot 6$ & 131 & 11.7 \\
\hline $\begin{array}{l}\text { (a) body weight } \\
\text { (b) FFM } \\
\text { (c) fat and FFM }\end{array}$ & \multicolumn{2}{|c|}{$\begin{array}{l}6551 \\
6620 \\
\text { NA } \ddagger\end{array}$} & \multicolumn{2}{|c|}{$\begin{array}{l}6882 \dagger \\
6801 \\
\text { NA } \ddagger\end{array}$} & \multicolumn{2}{|c|}{$\begin{array}{l}5004 \\
5042 \\
5044\end{array}$} & \multicolumn{2}{|c|}{$\begin{array}{l}5289 \dagger \\
5245 \\
5242\end{array}$} \\
\hline
\end{tabular}

FFM, fat-free mass; ANCOVA, analysis of covariance; NA, not applicable.

Mean values were significantly different from those for Indians of the corresponding sex, ${ }^{* *} P<0.005$ (independent $t$ test)

+ Significantly different from Indians of the corresponding sex, $P<0.05$.

$\ddagger$ Not applicable because fat mass is not a significant covariate. 


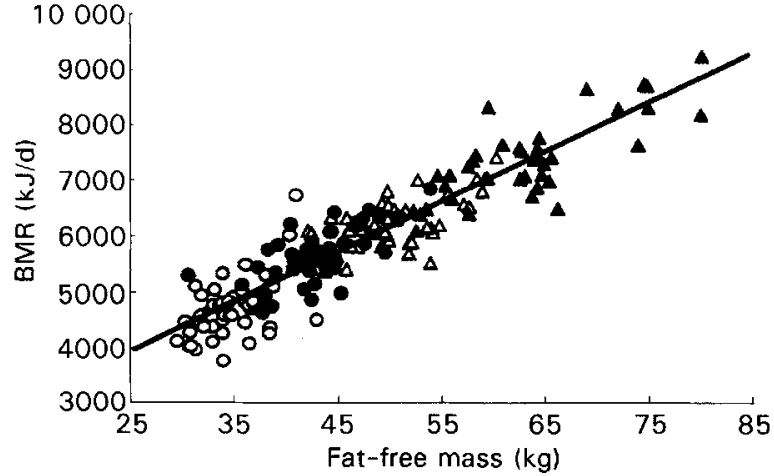

Fig. 1. Scatterplot of measured BMR v. fat-free mass of Indians and Australians with superimposed regression line. (O), Indian women; $(\triangle)$, Indian men; (O), Australian women; ( $\mathbf{\Delta})$, Australian men.

(df 1,$89 ; F$ ratio $5.67 ; P=0.02$ ) were significantly lower than their Australian counterparts. BMR adjusted for FFM was not significantly different between the two groups of men (df 1,$82 ; F$ ratio $2.02 ; P=0 \cdot 16$ ). BMR adjusted for either FFM alone (df 1,$89 ; F$ ratio $2.52 ; P=0.12$ ) or BMR adjusted for both FFM and FM (df 1,$88 ; F$ ratio 2.50 ; $P=0.12$ ) was not significantly different between the two groups of women.

Stepwise linear regression was used to relate BMR to potential predictor variables FFM, FM, and ethnicity $(0=$ Indian; $1=$ Australian $)$ in $50 \%$ of men and $50 \%$ of women separately. BMR was significantly related to FFM in men and to FFM and FM in women. These sexspecific equations were then tested on the half not used to generate the respective equation. Bias was not significant at -12 (SE 59) $\mathrm{kJ} / \mathrm{d}$ in men and not significant at -25 (SE $71) \mathrm{kJ} / \mathrm{d}$ in women, on the basis of paired $t$ tests. Bias in each sex group was unrelated to predicted BMR. The pooled data for each sex group resulted in the following equations:

$$
\text { men: } \mathrm{BMR}=81.5 \times \mathrm{FFM}(\mathrm{kg})+2131 \text {, }
$$

(n $85, r 0 \cdot 87, r^{2} 0 \cdot 76$, SEE 413), women: $\mathrm{BMR}=87 \times \mathrm{FFM}(\mathrm{kg})+29 \times \mathrm{FM}(\mathrm{kg})+1297$,

( $\left(\right.$ 92, $r 0 \cdot 80, r^{2} 0.64$, SEE 423).

From the data of all subjects (sex and ethnic groups combined), a random sample of $50 \%$ was selected. Stepwise multiple regression of $B M R(\mathrm{~kJ} / \mathrm{d})$ on the predictor variables FFM, FM, sex $(0=$ women; $1=$ men) and ethnicity $(0=$ Indian; $1=$ Australian) resulted in the following relationship:

$$
\begin{aligned}
& \mathrm{BMR}=88.6 \times \mathrm{FFM}(\mathrm{kg})+1726, \\
& \left(n 88, r 0.94 ; r^{2} 0.88 ; \text { SEE } 371 \mathrm{~kJ}\right) .
\end{aligned}
$$

When equation 8 was tested on the remaining eighty-nine subjects not used to generate the equation, bias was not significant at -17 (SE 50$) \mathrm{kJ} / \mathrm{d}$ (paired $t$ test; $t 0.34$; df 88; $P=0.70$ ). Within each subgroup, bias was also not significant for Indian women - 129 (SE 115$) \mathrm{kJ} / \mathrm{d}$, Indian men 39 (SE 83) kJ/d, Australian women 45 (SE 82) kJ/d and Australian men -15 (SE 120) kJ/d. A scatter plot of bias $v$. predicted BMR showed no trend $(r 0, P=0.96)$. The following equation was then derived from the entire dataset of 177 subjects:

$$
\begin{gathered}
\mathrm{BMR}=88.7 \times \mathrm{FFM}(\mathrm{kg})+1713, \\
\left(n 177 ; r 0.92 ; r^{2} 0.85 ; \mathrm{SEE} 425 \mathrm{~kJ}\right) .
\end{gathered}
$$

A scatterplot of measured BMR $v$. FFM with the superimposed regression line of equation 9 is provided in Fig. 1.

Equation 5 (Cunningham, 1991) resulted in a predicted: measured ratio of $99 \%(95 \%$ CI of mean: 97.9 $100.2 \%$ ) for the data on all subjects ( $n 177)$. This equation, based on FFM, accurately predicted the BMR of Indian men, Indian women and Australian men. In Australian women, however, the BMR was significantly underpredicted by $3 \%$ (Table 3 ). The North European and American equation of Hayter \& Henry (1994), based on body weight, significantly overestimated the BMR of Australian women by $3 \%$, but accurately predicted the BMR of Australian

\begin{tabular}{|c|c|c|c|c|c|c|c|c|}
\hline & \multicolumn{4}{|c|}{ Men } & \multicolumn{4}{|c|}{ Women } \\
\hline & \multicolumn{2}{|c|}{ Indian $(n 46)$} & \multicolumn{2}{|c|}{ Australian ( $n$ 39) } & \multicolumn{2}{|c|}{ Indian ( $n$ 50) } & \multicolumn{2}{|c|}{ Australian ( $(42)$} \\
\hline & Mean & SD & Mean & SD & Mean & SD & Mean & SD \\
\hline \multicolumn{9}{|c|}{ Hayter \& Henry (1994): North American and European equations based on body weight (equations 1 and 2) } \\
\hline Absolute bias $\dagger(\mathrm{kJ} / \mathrm{d})$ & $-368^{\star *}$ & 376 & -91 & 493 & $-478^{\star *}$ & 468 & $-129^{\star}$ & 369 \\
\hline Predicted: measured ratio (\%) & 106 & 6.5 & 102 & 6.7 & 111 & $10 \cdot 3$ & 103 & $7 \cdot 0$ \\
\hline \multicolumn{9}{|c|}{ Hayter \& Henry (1994): Indian equations based on body weight (equations 3 and 4) } \\
\hline Absolute bias $(\mathrm{kJ} / \mathrm{d})$ & $318^{* *}$ & 368 & $794^{\star \star}$ & 512 & $-409^{\star \star}$ & 492 & $181^{\star *}$ & 412 \\
\hline Predicted: measured ratio (\%) & 95 & $5 \cdot 8$ & 90 & 6.0 & 110 & $10 \cdot 6$ & 97 & $7 \cdot 3$ \\
\hline \multicolumn{9}{|c|}{ Cunningham (1991): based on fat-free mass (equation 5) } \\
\hline Absolute bias $(\mathrm{kJ} / \mathrm{d})$ & 93 & 376 & 69 & 468 & 9 & 450 & $185^{\star *}$ & 393 \\
\hline Predicted: measured ratio (\%) & 99 & $6 \cdot 2$ & 99 & 6.3 & 100 & $9 \cdot 2$ & 97 & $7 \cdot 1$ \\
\hline
\end{tabular}
men (Table 3). The Indian equation of Hayter \& Henry (1991) significantly overestimated BMR of Indian women

Table 3. Bias in predicted BMR using equations based either on body weight or fat-free mass

(Mean values and standard deviations)

Measured and predicted BMR values were significantly different, ${ }^{*} P<0.05,{ }^{* \star} P<0.005$ (paired $t$ test).

+ Bias = measured-predicted BMR. 
by $10 \%$ and underestimated measured BMR of Indian men by $5 \%$ (Table 3 ).

\section{Discussion}

A lower BMR of Indians when compared with their Western counterparts has been reported when data were expressed per unit surface area and compared with American standards (Rajagopal, 1938; Niyogi et al. 1939; Khanna \& Manchanda, 1946; Shiv Kumar \& Sachar, 1961; Banerjee, 1962) or when predicted from body weight using equations derived on European population groups (Schofield et al. 1985; McNeill et al. 1987; Soares \& Shetty, 1988; Piers \& Shetty, 1993). The main objective of the present study was to examine whether differences in body composition could account for these observations.

The study was based on data gathered in two locations and so it was important to use comparable and applicable methodologies for BMR and body composition. Previous studies had shown that methods for the measurement of BMR, based on the techniques reported here, were not significantly different from each other (Segal, 1987; Soares et al. 1989). Our measurements of body composition, based on the sum of four skinfolds and equations of Durnin \& Womersley (1974), were comparable with estimates derived from total body water in Australians (L. S. Piers, M. J. Soares and K. O'Dea, unpublished results). There were no differences in the FFM of Indians when obtained by the sum of four skinfolds approach or from hydrodensitometry. In addition, the observed precision ( $\mathrm{CV}$ $1.5 \%, \mathrm{SD} 0.29 \mathrm{~kg}$ ) for the measurement of body fat using this technique was within the range obtained by other investigators (Hill et al. 1978; Burkinshaw, 1985; King, 1985). Hence the sum of four skinfolds approach to body composition was applicable to each ethnic group studied and was expected to give consistent results. By using validated methodologies for BMR and body composition and keeping inter-observer bias to a minimum, we aimed to uncover the true extent of differences between the two ethnic groups studied.

\section{The influence of body weight on BMR}

Body weight is an easily measured variable with a strong positive relationship to BMR. Absolute BMR was significantly lower in Indians compared with Australians (Table 2) and so was body weight (Table 1). When values were adjusted for body weight, both Indian men and women still had significantly lower BMR compared with Australians (Table 2). This supported previous observations of a lower measured BMR of Indians, compared with that predicted from body weight using equations developed on European data (Schofield et al. 1985; Henry \& Rees, 1988). However, it contrasted with results that showed that the BMR of North Americans and Indians could be predicted from the same equation based on body weight (Piers \& Shetty, 1993; Soares et al. 1993). The present results need not be interpreted as supporting the contention of an ethnic influence on BMR. A lower BMR for the same body weight could well reflect differences in body composition, and this aspect needed to be explored.

\section{The relationship of BMR to fat-free mass}

When comparing two dissimilar groups the manner of expression of data is important, since BMR divided by FFM introduces a mathematical artifact that would suggest that the BMR per $\mathrm{kg}$ FFM of lighter individuals is greater than that of their heavier counterparts (Ravussin \& Bogardus, 1989; Weinsier et al. 1992). FFM is not a homogeneous tissue mass (Lawrence et al. 1988; Waterlow, 1988) and within a range of FFM the proportions of OM (which has a high metabolic activity at rest relative to SSM), and SMM will vary. A greater OM:SMM ratio would also explain why BMR expressed per kg FFM is 'higher' in those with a smaller FFM (Soares \& Shetty, 1991; Shetty, 1993). This concept is consistent with our previous observations that the OM:SMM ratio was an important determinant of BMR and whole-body protein turnover (Soares et al. 1994) and would account for the apparently higher BMR per $\mathrm{kg}$ FFM of Indian men compared with Australian men and of women compared with men, seen in the present study (Table 2).

When we adjusted for FFM, using an ANCOVA, there were no significant differences in BMR between Indian and Australian men (Table 2). The residual difference in adjusted BMR between groups (Table 2) may, in part, be ascribed to the variance in BMR associated with alterations in the OM : SMM ratio within FFM, and in part, to the contribution of variations in organ size to energy expenditure. In the present study, the residual difference of $180 \mathrm{~kJ} / \mathrm{d}$ was small and not significant in men (Table 2). Similar results were obtained in women. In the latter case, both FFM and FM were significant covariates in the intergroup comparison and the residual difference amounted to $200 \mathrm{~kJ} / \mathrm{d}$ (Table 2). It is noteworthy that the residual variance in BMR amounted to $2.7 \%$ and $3.9 \%$ of the grand mean, for men and women respectively. This is within the contribution of $5 \%$ made by variations in the weights of organs, i.e. liver, heart, brain, kidneys and gut, to energy expenditure (Garby \& Lammert, 1994). We therefore conclude that the BMR of Indians and Australians are similar when adjusted for differences in body composition. Banerjee (1962) viewed the lower absolute BMR of Indians as the result of an interaction between climate and body composition. So, when BMR data were related to cell mass, cell solids or lean tissue mass, there were no differences between BMR of Indians and Europeans. The results of the present study support the early observations of Banerjee (1962).

\section{Prediction of BMR from body weight}

The decision to isolate the Italian data and partition the existing FAO/WHO/UNU (1985) database into groups of 'tropical' and 'temperate' populations is an improvement on the older equations. It acknowledges that the relationship of BMR to body weight is not necessarily similar in each geographical group (Hayter \& Henry, 1994). With the use of equations based on body weight, the underlying assumption is that there are no serious differences in body composition between the population used to derive the equation and the population it is applied to. 
We have previously shown that the North European and American equations of Hayter \& Henry (1994) are valid for Australian men and women of European descent, with a small over-prediction of the BMR of women not taking oral contraceptives (Piers et al. 1997). This supports the use of these equations in this population group. The Indian equations of Hayter \& Henry (1994) were yet to be validated. We expected the Indian equations to underestimate the Australian data in general while accurately predicting the BMR of Indians. This would fit in with the observation of a lower BMR adjusted for body weight in Indians as compared with Australians (Table 2). However, the new Indian equation systematically underestimated measured BMR of Indian men by $5 \%$ and overestimated BMR of Indian women by $10 \%$ (Table 3 ). The magnitude of these differences is beyond the expected limits of technical and methodological error, inherent in any large compilation of BMR data. Furthermore, they are in opposite directions. One possibility could involve variations in body composition between the older Indian data used to formulate these equations and the Indian data in the present study. Future validation of these equations is necessary before they are considered for the prediction of BMR and hence energy requirements of the Indian population.

\section{Prediction of BMR from body composition}

The results suggested that differences in BMR between the two ethnic groups were evident only when data were examined using body weight as the determinant of BMR. Equations based on body weight also resulted in significant errors in predicting BMR of Indians. As a logical step we explored the possibility of using a two-compartment model of body composition to predict BMR. The lack of differences in BMR adjusted for FFM, between ethnic or sex groups justified pooling of the data on all subjects to determine the best predictive equation for BMR.

The contribution of FM to BMR, at moderate degrees of fatness, is expected to be small (Durnin, 1996). Once FFM enters a stepwise regression equation, FM seldom makes a sizeable contribution to the variance in BMR (Lawrence et al. 1988; Cunningham, 1991; Nelson et al. 1992). This is particularly true of mixed-sex equations (Cunningham, 1991). Hence the variability in FFM determines, to a major degree (at least $80 \%$ ), the variability in BMR. The relationship obtained in the present study reflected these conclusions, with FFM being the only significant predictor of $B M R$ and accounting for $85 \%$ of the variance in BMR (equation 9). The slope and intercept of equation 9 (Fig. 1) were similar to the corresponding terms derived from a synthesis of published data that included Japanese, Americans, Europeans and American Indians of both sexes, who ranged from lean to obese (Cunningham, 1991).

On using the Cunningham (1991) equation (equation 5), the overall predicted: measured BMR ratio was $99 \%$. In addition, measured BMR was accurately predicted in Indian men, Indian women and Australian men (Table 3). Nelson et al. (1992) had also reported an accurate prediction of BMR using the Cunningham (1991) equation, with a predicted:measured ratio of $99.4 \%$. The small underprediction of the BMR of Australian women (Table 3) possibly reflects the significant contribution of FM to BMR in these women (see equation 7). Such data support the proposition that, in some instances, the inclusion of FM as a predictor variable is of benefit (Garby et al. 1988; Henshka et al. 1990). The excellent prediction of BMR from FFM would suggest that the way forward would be to collate more data on BMR and body composition of different population groups. This could provide the basis for an improved prediction of BMR worldwide and possibly result in a single generalized equation.

In conclusion, this analysis has shown that differences in the BMR of Indians and Australians are explained by differences in body composition. Hence, there is no evidence to support an ethnic influence on BMR, a view shared by Lawrence et al. (1988). Unless the amounts of FFM and FM are similar across the population groups studied, generalized equations based on body weight would result in a significant bias in predicted BMR. The latter practice has, in part, contributed to the belief of an ethnic influence on BMR. When interested in predicting the BMR of population groups of differing body size and composition, it is preferable to use FFM as a predictor variable; the equation of Cunningham (1991) is an example. In some situations, especially when FM makes a sizeable contribution to body weight, the inclusion of FM would improve the prediction of BMR. In sedentary to moderately active population groups, the accuracy of predicting BMR would translate to improved estimates of human energy requirements.

\section{Acknowledgements}

L.S.P. is the recipient of a fellowship from Deakin University, Australia. The authors thank Dr Sing Kai Lo for statistical comments and Dr Anura V. Kurpad for data on validation of body composition techniques in Indians. The data presented in this paper were collected in studies supported by The Food and Agriculture Organization (FAO), Rome, The Indian Council of Medical Research (ICMR), New Delhi, India and Deakin University, Melbourne, Australia.

\section{References}

Banerjee S (1962) Studies in Energy Metabolism. Indian Council of Medical Research Special Report Series no. 43. New Delhi: Indian Council of Medical Research.

Bland JM \& Altman DG (1986) Statistical methods for assessing the agreement between two methods of clinical measurement. Lancet 1, 307-310.

Burkinshaw L (1985) Measurements of human body composition in vivo. In Progress in Medical Radiation Physics, vol. 2, pp. 113-137 (CG Orton, editor]. New York: Plenum Publishing Corporation.

Clark HD \& Hoffer LJ (1991) Reappraisal of the resting metabolic rate of normal young men. American Journal of Clinical Nutrition 53, 21-26.

Cunningham JJ (1991) Body composition as a determinant of energy expenditure: a synthetic review and a proposed general 
prediction equation. American Journal of Clinical Nutrition 54, 963-969.

Daly JM, Heymsfield SB, Head CA, Harvey LP, Nixon DW, Katzeff H \& Grossman GD (1985) Human energy requirement: overestimation by widely used prediction equation. American Journal of Clinical Nutrition 42, 1170-1174.

de Boer JO, van Es AJH, Voorrips LE, Blockstra F \& Vogt JE (1988) Energy metabolism and requirements in different ethnic groups. European Journal of Clinical Nutrition 42, 983-997.

Draper NR \& Smith H (1981) Applied Regression Analysis, 2nd ed. New York: John Wiley and Sons.

Durnin JGVA (1996) Energy requirements: general principles. European Journal of Clinical Nutrition 50, Suppl. 1, S2-S9.

Durnin JVGA \& Womersley J (1974) Body fat assessed from total body density and its estimation from skinfold thickness: measurement on 481 men and women aged 16-72 years. British Journal of Nutrition 32, 77-97.

Food and Agriculture Organization/World Health Organization/United Nations University (1985) Energy and Protein Requirements. Technical Report Series no. 724. Geneva: World Health Organization.

Garby L, Garrow JS, Jorgensen B, Lammert O, Madsen K, Sorensen P \& Webster J (1988) Relation between energy expenditure and body composition in man: specific energy expenditure in vivo of fat and fat-free tissue. American Journal of Clinical Nutrition 42, 301-305.

Garby L \& Lammert O (1992) An explanation for the nonlinearity of the relation between energy expenditure and fat free mass. European Journal of Clinical Nutrition 46, 235-236.

Garby L \& Lammert O (1994) Between-subject variation in energy expenditure: estimation of the effect of variation in organ size. European Journal of Clinical Nutrition 48, 376378.

Harris JA \& Benedict FG (1919) A Biometric Study of Basal Metabolism in Man. Publication no. 279. Washington: Carnegie Institution.

Harrison GC, Buskirk ER, Lindsay Carter JE, Johnston FE, Lohman TG, Pollock ML, Roche AF \& Wilmore J (1988) Skinfold thicknesses and measurement technique. In Anthropometric Standardization Reference Manual, pp. 55-70 [TG Lohman, AF Roche and R Martorell, editors]. Champaign, IL: Human Kinetics Books.

Hayter JE \& Henry CIK (1993) Basal metabolic rate in human subjects migrating between tropical and temperate regions: a longitudinal study and review of previous work. European Journal of Clinical Nutrition 47, 724-734.

Hayter JE \& Henry CIK (1994) A re-examination of basal metabolic rate predictive equations: the importance of geographic origin of subjects in sample selection. European Journal of Clinical Nutrition 48, 702-707.

Henry CJK, Piggott S \& Emery B (1987) Basal metabolic rate and diet-induced thermogenesis in Asians living in Britain. Human Nutrition: Clinical Nutrition 41C, 397-402.

Henry CJK \& Rees DG (1988) A preliminary analysis of basal metabolic rate and race. In Comparative Nutrition, Proceedings of the Rank Prize Funds International Symposium on Nutrition, pp. 149-159 [K Blaxter and I Macdonald, editors]. London: John Libbey.

Henry CJK \& Rees DG (1991) New predictive equations for the estimation of basal metabolic rate in tropical peoples. European Journal of Clinical Nutrition 45, 177-185.

Heshka S, Yang MU, Wang J, Burt P \& Pi-Sunyer FX (1990) Fat loss and change in resting energy expenditure. American Journal of Clinical Nutrition 52, 981-986.

Hill GL, McCarthy ID, Collins JP \& Smith AH (1978) A new method for the rapid measurement of body composition in critically ill surgical patients. British Journal of Surgery $\mathbf{6 5}$, $732-791$.

Hill JO, Heymsfield SB, McMannus C \& DiGirolamo M (1984) Meal size and thermic response to food in male subjects as a function of maximum aerobic capacity. Metabolism 33, 743749.

James WPT, Ferro-Luzzi A \& Waterlow JC (1988) Definition of CED in adults. Report of a working party of the International Dietary and Energy Consultative Group. European Journal of Clinical Nutrition 42, 969-981.

Khanna LC \& Manchanda SS (1946) Basal metabolic studies in Punjab. Indian Medical Gazette 81, 458-460.

King RFGJ (1985) The assessment of short term changes in body fat by skinfold, body compartment and gas exchange measurement. In Human Body Composition and Fat Distribution. Report no. 8, pp. 81-91 [NG Norgan, editor]. Wageningen: EURO-NUT.

Klausen B, Toubro S \& Astrup A (1997) Age and sex effects on energy expenditure. American Journal of Clinical Nutrition $\mathbf{6 5}$, 895-907.

Kleinbaum DG, Kupper LL \& Muller KE (1988) Applied Regression Analysis and Other Multivariate Methods, 2nd ed. Boston: PWS-KENT Publishing Company.

Krishnan BT \& Vareed C (1932) Basal metabolism of young college students, men and women in Madras. Indian Journal of Medical Research 20, 831-858.

Lawrence M, Thongprasert K \& Durnin JGVA (1988) Betweengroup differences in basal metabolic rate: an analysis of data collected in Scotland, The Gambia and Thailand. European Journal of Clinical Nutrition 42, 877-891.

McNeill G, Rivers JPR, Payne PR, de Britto JJ \& Abel R (1987) Basal metabolic rate of Indian men: no evidence of metabolic adaptation to a low plane of nutrition. Human Nutrition: Clinical Nutrition 41C, 473-483.

Mahadeva K (1954) The energy expenditure at rest of Southern Asiatics in Britain. Indian Journal of Medical Research 42, 181-190.

Mason ED \& Benedict FG (1931) The basal metabolism of South Indian women. Indian Journal of Medical Research 19, 75-98.

Mason ED, Mundkur V \& Jacob M (1963) Basal energy metabolism and heights, weights, arm skinfold and muscle of young Indian women in Bombay, with prediction standards for BMR. Indian Journal of Medical Research 51, 925-932.

Mifflin MD, St-Jeor ST, Hill LA, Scott BJ, Daugherty SA \& Koh YO (1990) A new predictive equation for resting energy expenditure in healthy individuals. American Journal of Clinical Nutrition 51, 241-247.

Mukherjee HN \& Gupta PC (1931) The basal metabolism of Indians (Bengalis). Indian Journal of Medical Research 11, 807-811.

Munro AF (1950) Basal metabolic rates and physical fitness scores of British and Indian males in the tropics. Journal of Physiology 110, 356-366.

Nelson KM, Weinsier RL, Long CL \& Schutz Y (1992) Prediction of resting energy expenditure from fat-free mass and fat mass. American Journal of Clinical Nutrition 56, 848-856.

Niyogi SP, Patwardhan UN \& Modecai J (1939) Studies on basal metabolism in Bombay. Indian Journal of Medical Research 27, 99-133.

Owen OE, Holup JL, D'Allessio DA, Craig ES, Polansky M, Smalley KJ, Kavle EC, Bushman MC, Owen LR, Mozzoli MA, Kendrick ZV \& Boden GH (1987) A reappraisal of the caloric requirements of men. American Journal of Clinical Nutrition 46, 875-885.

Owen OE, Kavle E, Owen RS, Polansky M, Caprio S, Mozzoli MA, Kendrick ZV, Bushman MC \& Boden G (1986) A 
reappraisal of caloric requirements in healthy women. American Journal of Clinical Nutrition 44, 1-19.

Piers LS, Diffey B, Soares MJ, Frandsen SL, McCormack LM, Lutschini MJ \& O'Dea K (1997) The validity of predicting the basal metabolic rates of young Australian men and women. European Journal of Clinical Nutrition 51, 333-337.

Piers LS \& Shetty PS (1993) Basal metabolic rates of Indian women. European Journal of Clinical Nutrition 47, 586-591.

Quenouille MH, Boyce AW, Fisher WB \& Leitch I (1951) Statistical Analysis of Recorded Energy Expenditure of Men. Part 1. Basal Metabolism Related to Sex, Stature, Age, Climate and Race. Commonwealth Bureau of Animal Nutrition Technical Communications no. 17. Aberdeen: Commonwealth Agricultural Bureau.

Rahman SA (1936) Basal metabolism of young men at Hyderabad, Deccan, with a study of their physical characters. Indian Journal of Medical Research 24, 173-199.

Rajagopal K (1938) The basal metabolism of Indian and European men on the Nilgiris Hills (S. India). Indian Journal of Medical Research 26, 411-426.

Ravussin E \& Bogardus C (1989) Relationship of genetics, age and physical activity to daily energy expenditure and fuel utilization. American Joumal of Clinical Nutrition 49, 968975.

Roza AM \& Shizgal HM (1984) The Harris Benedict equation reevaluated: resting energy requirements and the body cell mass. American Journal of Clinical Nutrition 40, 168-182.

Schofield WN, Schofield C \& James WPT (1985) Basal metabolic rate - review and prediction together with an annotated bibliography of source material. Human Nutrition: Clinical Nutrition 39C, Suppl. 1, 5-96.

Segal KR (1987) Comparison of indirect calorimetric measurements of resting energy expenditure with ventilated hood, face mask and mouthpiece. American Journal of Clinical Nutrition 45, 1420-1423.

Shetty PS (1993) Chronic undernutrition and metabolic adaptation. Proceedings of the Nutrition Society 52, 267-284.

Shetty PS, Henry CJK, Black AE \& Prentice AM (1996) Energy requirements of adults: an update on basal metabolic rates (BMRs) and physical activity levels (PALs). European Journal of Clinical Nutrition 50, Suppl. 1, S11-S23.

Shetty PS, Soares MJ \& Sheela ML (1988) Basal Metabolic Rates of South Indian Males. Bangalore, India: FAO.
Shiv Kumar NK \& Sachar RS (1961) Basal metabolic rate in normal Indian adult males. Indian Journal of Medical Research 49, 702-709.

Soares MJ, Francis DG \& Shetty PS (1993) Predictive equations for basal metabolic rates of Indian males. European Journal of Clinical Nutrition 47, 389-394.

Soares MJ, Piers LS, Shetty PS, Jackson AA \& Waterlow JC (1994) Whole body turnover in chronically undernourished individuals. Clinical Science 86, 441-446.

Soares MJ, Sheela ML, Kurpad AV, Kulkami RN \& Shetty PS (1989) The influence of different methods on basal metabolic rate measurements in human subjects. American Journal of Clinical Nutrition 50, 731-736.

Soares MJ \& Shetty PS (1984) Resting metabolic rates of Indian subjects with low body mass index on normal energy intakes. In Human Energy Metabolism: Physical Activity and Energy Expenditure Measurements in Epidemiological Research Based upon Direct and Indirect Calorimetry, pp. 227-228 [JH van Es, editor]. Wageningen: EURO-NUT Report 5.

Soares MJ \& Shetty PS (1988) Validity of Schofield's predictive equations for basal metabolic rates of Indians. Indian Journal of Medical Research 88, 253-260.

Soares MJ \& Shetty PS (1991). Basal metabolic rates and metabolic economy in chronic undernutrition. European Journal of Clinical Nutrition 45, 363-373.

Solomon SJ, Kurzer MS \& Calloway DH (1982) Menstrual cycle and basal metabolic rate in women. American Journal of Clinical Nutrition 36, 611-616.

Stoner HB (1982) Assessment of energy expenditure. Proceedings of the Nutrition Society 41, 349-353.

Ulijaszek SJ \& Strickland SS (1991) Basal metabolic rate and physique of Gurkha and British soldiers stationed in Britain. Annals of Human Biology 18, 245-251.

Waterlow JC (1988) The variability of energy metabolism in man. In Comparative Nutrition, pp. 133-139 [K Blaxter and JC Waterlow, editors]. London: John Libbey \& Company.

Weinsier RL, Schutz Y \& Bracco D (1992) Reexamination of the relationship of resting metabolic rate to fat-free mass and to the metabolically active components of fat-free mass in humans. American Journal of Clinical Nutrition 55, 790-794.

Wilson EA (1945) Basal metabolism from the standpoint of racial anthropology. American Journal of Physical Anthropology 3 $1-19$. 